\title{
Pengaruh Model Kooperatif Tipe Snowball Throwing Berbasis Penilaian PortofolioTerhadap Hasil Belajar PKn
}

\author{
Kadek Mita Yuniari ${ }^{1}$, Ni Ketut Suarni ${ }^{2}$, Desak Putu Parmiti ${ }^{3}$ \\ ${ }^{13}$ Jurusan PGSD, Jurusan BK ${ }^{2}$, Fakultas IImu Pendidikan \\ Universitas Pendidikan Ganesha \\ e-mail: mita.yuniari@yahoo.com ${ }^{1}$, niketut.suarni@undiksha.ac.id ${ }^{2}$ \\ dskpt parmiti@yahoo.co.id ${ }^{3}$
}

\begin{abstract}
Abstrak
Penelitian ini bertujuan untuk mengetahui pengaruh yang signifikan hasil belajar PKn antara siswa yang dibelajarkan dengan model pembelajaran kooperatif tipe Snowball Throwing berbasis penilaian portofolio dengan siswa yang dibelajarkan dengan model pembelajaran konvensional. Penelitian ini adalah eksperimen semu (Quasi Exsperimen), dengan desain Non Equivalent post test only control grup desain. Populasi penelitian ini adalah seluruh siswa kelas IV SD di Gugus I Kecamatan Sawan. Sampel penelitian ini adalah siswa kelas IV SDN 1 Sekumpul dan siswa kelas IV SD N 2 Lemukih. Sampel ditentukan dengan menggunakan teknik Random Sampling. Data hasil belajar dikumpulkan dengan menggunakan tes pilihan ganda. Data yang diperoleh dianalisis menggunakan teknik analisis statistik deskriptif dan statistik inferensial uji-t dengan rumus polled varians. Hasil penelitian menunjukkan bahwa terdapat pengaruh yang signifikan pada hasil belajar PKn antara siswa yang dibelajarkan dengan model pembelajaran kooperatif tipe Snowball Throwing berbasis penilaian portofolio dengan siswa yang dibelajarkan dengan model pembelajaran konvensional pada siswa kelas IV SD di Gugus I Kecamatan Sawan. Hal ini ditunjukkan oleh $t_{\text {hitung }}=(5,679) \geq t_{\text {tabel }}=(2,028)$. Selanjutnya, ratarata (mean) kelompok eksperimen $(21,40)$ lebih besar daripada rata-rata (mean) kelompok kontrol $(16,8)$. Dengan demikian, model pembelajaran kooperatif tipe Snowball Throwing berbasis penilaian portofolio memiliki pengaruh signifikan terhadap hasil belajar PKn siswa kelas IV di Gugus I Kecamatan Sawan Tahun Pelajaran 2017/2018.
\end{abstract}

Kata Kunci: Snowball Thowing, hasil belajar, portofolio

\begin{abstract}
The aim of this research is to know about the influence of significant PKn Learning outcomes between the students with a cooperative learning model about the Snowball Throwing type in portfolio assessment with students in the conventional learning model. This research is a Quasi-Experiment with Non-equivalent post test only control group design. The study population school Gugus I Sawan districts. The sample of this research is the student in IV grade SDN 1 Sekumpul and student in IV grade SDN2 Lemukih. This sample determined with Random Sampling techniques. The results of learning data collected using statistics analysis descriptive and analysis inferential t-test with polled variance formula. The result of this research showed a significant influence in PKn Snowball Throwing type in portfolio assessment with students in the conventional learning model in IV grade Gugus I Sawan districts. This is indicated by $t_{\text {-hitung }}=$ $(5,679) \geq t_{\text {tabel }}=(2,028)$. After that mean group experiment $(21,40)$ higher than the mean of group control $(16,8)$. The cooperative learning model about Snowball Throwing type in portfolio assessment has a significant influence on the learning result of PKn in student IV grade Gugus I Sawan district years of learning 2017/2018.
\end{abstract}

Keywords: Snowball Throwing, the result of learning, portfolio. 


\section{Pendahuluan}

Pendidikan merupakan suatu proses di mana pengalaman dan informasi diperoleh sebagai hasil belajar, yang mencakup pengertian dan penyesuaian diri dari pihak peserta didik terhadap rangsangan yang diberikan kepadanya menuju ke arah pertumbuhan dan perkembangan. Dengan demikian, pendidikan di sekolah dipengaruhi oleh beberapa faktor antara lain: guru, metode/pendekatan/model pembelajaran, kurikulum, media pengajaran, dan peserta didik (Monawati, 2016).

Pendidikan adalah suatu proses yang diperlukan untuk mendapatkan keseimbangan dan kesempurnaan dalam perkembangan individu maupun masyarakat. Penekanan pendidikan dibanding dengan pengajaran terletak pada pembentukan kesadaran dan kepribadian individu atau masyarakat di samping transfer ilmu dan keahlian. Dengan proses semacam ini suatu bangsa atau negara dapat mewariskan nilai-nilai keagamaan, kebudayaan, pemikiran dan keahlian kepada generasi berikutnya, sehingga mereka betul-betul siap menyongsong masa depan kehidupan bangsa dan negara yang lebih cerah (Nurkholis ,2013).

Perkembangan sumber daya manusia merupakan bagian penting dalam dunia pendidikan. Pendidikan yang berkualitas akan menghasilkan sumber daya manusia yang berkualitas pula. Undang Undang Nomor 20 Tahun 2003 pasal 1 tentang Sistem Pendidikan Nasional menyatakan, pendidikan adalah usaha sadar dan terencana untuk mewujudkan suasana belajar dan proses pembelajaran agar peserta didik secara aktif mengembangkan potensi dirinya untuk memiliki kekuatan spiritual keagamaan, pengendalian diri, kepribadian, kecerdasan, akhlak mulia, serta keterampilan yang diperlukan dirinya, masyarakat, bangsa dan Negara.

Tujuan Pendidikan Nasional Indonesia bersumber pada pandangan hidup bermasyarakat, berbangsa dan bernegara yaitu pancasila, itu berarti pendidikan di Indonesia harus membawa peserta didik agar menjadi manusia yang berpancasila. Nilai-nilai falsafah pancasila yang dianut oleh bangsa Indonesia dicerminkan dalam tujuan pendidikan nasional seperti yang terdapat pada pasal 3 Undang-Undang Nomor 20 Tahun 2003 tentang Sistem Pendidikan Nasional

Untuk mencapai tujuan pendidikan nasional dapat melalui pendidikan formal, informal, dan non formal. Pendidikan formal merupakan pendidikan yang diselenggarakan di sekolah. Pendidikan yang dilaksakan di sekolah tidak lepas dari ketentuan yang berlaku, salah satunya dengan mengembangkan kurukulum yang berlaku.

Pendidikan kewarganegaraan adalah mata pelajaran yang digunakan sebagai wahana mengembangkan dan melestarikan nilai luhur dan moral yang berakar pada budaya bangsa Indonesia (Susanto, 2013:225). Pembelajaran PKn di sekolah dasar dimaksudkan sebagai suatu proses belajar mengajar dalam rangka membantu peserta didik agar dapat belajar dengan baik dan membentuk manusia Indonesia seutuhnya dalam pembentukan karakter bangsa yang diharapkan mengarah pada penciptaan suatu masyarakat yang menempatkan demokrasi dalam kehidupan berbangsa dan bernegara yang berlandaskan pada Pancasila, UUD, dan norma-norma yang berlaku di masyarakat yang diselenggarakan selama enam tahun.

Mulyasa, 2007 (dalam Susanto 2013:231) menyatakan tujuan pembelajaran PKn yaitu,(1) mampu berpikir secara kritis, rasional, dan kreatif dalam menanggapi persoalan hidup maupun isu kewarganegaraan di negaranya, (2) mampu berpartisipasi dalam segala bidang kegiatan secara aktif dan bertanggung jawab, sehingga bias bertindak secara cerdas dalam semua kegiatan, dan (3) bisa berkembang secara positif dan demokratis sehingga mampu hidup bersama dengan bangsa lain di dunia dan mampu berinteraksi, serta mampu memanfaatkan teknologi, informasi dan komunikasi dengan baik dengan apa yang disampaikan. Namun saat ini pelajaran PKn menjadi pelajaran yang kurang diminati siswa. Hal ini terjadi karena pembelajaran PKn masih memakai metode ceramah. Metode ceramah lebih menekankan guru sebagai pemberi informasi, sedangkan peserta didik lebih diposisikan sebagai pendengar dan mencatat sehingga interaksi yang terjadi saat pembelajaran PKn hanya satu arah yaitu dari guru ke siswa. Dengan menjadikan siswa sebagai pendengar maka akan membuat aktivitas dan pengetahuan siswa terbatas dari apa yang di sampaikan oleh guru saja. Berdasarkan dari model yang dipakai, guru merasa apa yang disampaikan sudah dapat diterima dan dapat mengajar dengan baik padahal siswanya kurang mengerti dengan apa yang disampaikan.

Berdasarkan hasil wawancara dengan guru mata pelajaran PKn pada tanggal 09 Desember 2017, ditemukan permasalahan guru jarang menggunakan model pembelajaran dan 
hanya menggunakan metode ceramah dalam mengajar. Buku pelajaran Pkn di sekolah masih terbatas sehingga guru kesulitan memberikan pembelajaran, karena tanpa membaca buku tersebut siswa kurang memahami apa yang di sampaikan oleh gurunya. Hal tersebut berdampak pada hasil belajar PKn yang diperoleh siswa.

Selain wawancara dengan guru, dilakukan observasi untuk melihat proses pembelajaran PKn yang dilaksanakan guru di kelas. Hasil observasi yang diperoleh yaitu, (1) dalam proses pembelajaran yang dilakukan oleh guru masih banyak siswa yang pasif, dan (2) pembelajaran masih berpusat pada guru. Hal tersebut juga berpengaruh pada hasil belajar PKn siswa.

Tabel 1. Hasil Ulangan Akhir Semester PKn Kelas IV di Gugus 1 Kecamatan Sawan tahun pelajaran $2017 / 2018$

\begin{tabular}{|c|c|c|c|c|c|c|c|}
\hline \multirow[t]{2}{*}{ No } & \multirow[t]{2}{*}{ Sekolah } & \multirow[t]{2}{*}{ KKM } & \multicolumn{2}{|c|}{$\begin{array}{l}\text { Jumlah siswa } \\
\text { memenuhi KKM }\end{array}$} & \multicolumn{2}{|c|}{$\begin{array}{l}\text { Jumlah siswa } \\
\text { tidak memenuhi } \\
\text { KKM }\end{array}$} & \multirow[t]{2}{*}{$\begin{array}{c}\text { Jumlah } \\
\text { siswa }\end{array}$} \\
\hline & & & Siswa & $\%$ & Siswa & $\%$ & \\
\hline 1 & SD N 1 Sekumpul & 68 & 9 & 45 & 11 & 55 & 20 \\
\hline 2 & SD N 1 Galungan & 70 & 12 & 48 & 13 & 52 & 25 \\
\hline 3 & SD N 1 Lemukih & 70 & 15 & 50 & 15 & 50 & 30 \\
\hline 4 & SD N 2 Lemukih & 68 & 7 & 38,9 & 11 & 61,1 & 18 \\
\hline \multirow[t]{2}{*}{5} & SD N 3 Lemukih & 70 & 10 & 40 & 15 & 60 & 25 \\
\hline & Jumlah & & 53 & 221,9 & 65 & 278,1 & 118 \\
\hline
\end{tabular}

Berdasarkan persentase jumlah siswa yang memenuhi KKM dapat diketahui bahwa jumlah siswa kelas IV di Gugus I Kecamatan Sawan tahun pelajaran 2017/2018 sebanyak 118 siswa, dengan 44\% (53 siswa) sudah mencapai KKM dan 56\% (65 siswa) belum mencapai KKM. Artinya bahwa, hasil belajar PKn masih rendah. Hal ini merupakan suatu masalah yang harus diatasi agar hasil belajar siswa menjadi lebih baik.

Untuk itu salah satu solusi yang tepat untuk mengatasi permasalahan dalam pelajaran PKn yaitu dengan menggunakan model pembelajaran kooperatif tipe Snowball Throwing, karena model pembelajaran kooperatif tipe Snowball Throwing dapat membangkitkan semangat yang tinggi serta meningkatkan hasil belajar siswa dalam mata pelajaran PKn. Wuri Wuryandani \& Fatturohman (2012:59) menyatakan pembelajaran kooperatif yaitu salah satu pembelajaran yang dapat diterapkan untuk dapat mewujudkan kelas sebagai laboratorium demokrasi bagi siswa. Melalui pembelajaran kooperatif diharapkan akan menciptakan suasana kelas yang demokratis yang dapat dijadikan bekal untuk untuk diaplikasikan dalam kehidupan bermasyarakat, berbangsa dan bernegara. Model pembelajaran "Snowball Throwing merupakan pembelajaran yang diadopsi pertama kali dari game fisik dimana segumpalan salju yang dilempar dengan maksud memukul orang lain" (Huda 2013:226). Model ini diterapkan dengan melempar segumpalan kertas yang berisi pertanyaan yang diremas menjadi bola kertas lalu di lemparkan kepada siswa lain dan siswa yang di haruskan menjawab soal dari teman yang melempar pertanyaan. Model ini di gunakan untuk memberikan konsep pemahaman materi yang sulit kepada siswa serta dapat juga digunakan untuk mengetahui sejauh mana pengetahuan dan kemampuan siswa dengan materi tersebut.

Model pembelajaran merupakan rencana, pola atau pengaturan kegiatan pendidik dan peserta didik yang menunjukkan adanya interaksi antara unsur-unsur yang terkait dalam pembelajaran yakni guru, siswa dan media termasuk bahan ajar atau materi subyeknya. Dalam hal ini, baik guru atau siswa semuanya melaksanakan proses belajar. Guru mengajarkansiswa agar memperoleh pengalaman belajar berbentuk materi pelajaran yakni konsep-konsep, fakta dan teori. Pengetahuan tentang model pembelajaran dimaksudkan agar guru memiliki beberapa pilihan mengenai cara mengajar agar dapat mencapai tujuan pembelajaran. Perlu disadari bahwa tidak ada satupun model pembelajaran yang baik atau tepat untuk setiap topik, akan tetapi setiap topik dapat didekati dengan model-model tertentu, dan pilihan itu ditentukan oleh pelaksana kurikulum atau pelaksana pembelajaran yaitu guru (Yuliati ,2015).

Jika model pembelajaran tipe snowball throwing dipadukan dengan penilaian portofolio akan mendapatkan hasil penilaian jauh lebih kompleks dan mencangkup aspek-aspek tertentu. Oleh karena itu, karya-karya peserta didik harus dinilai dari waktu ke waktu sesuai dengan materi pembelajaran yang diberikan. Adapun penilaian yang dapat digunakan yaitu penilaian portofolio. Portofolio adalah sekumpulan artefak (bukti karya/kegiatan/data) sebagai bukti (evidance) yang menunjukkan perkembangan dan pencapaian suatu program (Masnur, 2011: 
73). Bisa mencakup kemajuan akademik peserta didik/kelompok, prestasi belajar, keterampilan maupun sikap. Untuk itu melalui penilaian portofolio diharapkan guru dapat mengajar dengan menggunakan penilaian yang sistematis, baik mata pelajaran PKn maupun mata pelajaran yang lain.

Salah Satu tipe dalam pembelajaran kooperatif yang dapat digunakan adalah tipe snowball throwing. Menurut Zaini (2007) metode pembelajaran kooperatif tipe snowball throwing adalah metode yang digunakan untuk mendapatkan jawaban yang dihasilkan dari diskusi siswa secara bertingkat. Dimulai dari kelompok kecil kemudian dilanjutkan dengan kelompok yang lebih besar sehingga pada akhirnya akan memunculkan dua atau tiga jawaban yang telah disepakati oleh siswa secara berkolompok (Ramlah ,2017).

Model pembelajaran kooperatif tipe Snowball Throwing dapat menigkatkan aktivitas dan kreatifitas siswa, melatih siswa belajar mandiri dalam pengetahuan berdasarkan diskusi, mengembangkan kemampuan berpikir siswa dalam mendiskusikan dan meyelesaikan tugas belajar, mengembangkan kemampuan mengemukakan pendapat, meningkatkan kemampuan menjelaskan kembali materi yang diperoleh berdasarkan diskusi, dan meningkatkan hasil belajar siswa (Rosidah ,2017).

Melalui model pembelajaran kooperatif tipe Snowball Throwing berbasis penilaian portofolio diharapkan siswa untuk lebih tanggap menerima pesan dari orang lain dan menyampaikan pesan tersebut kepada teman satu kelompoknya. Selain itu di harapkan pelajaran PKn dapat meningkatkan semangat siswa dalam belajar sehingga tercapainya tujuan pembelajaran secara optimal. Jadi pembelajaran tidak hanya berpusat pada guru dan sebatas dari apa yang disampaikan oleh guru, serta siswa lebih aktif dalam pembelajaran.

Berdasarkan pemaparan di atas, maka dapat dilaksanakan penelitian eksperimen dengan judul "pengaruh model pembelajaran kooperatif tipe snowball throwing berbasis penilaian portofolio terhadap hsil belajar PKn siswa kelas IV gugus I kecamatan Sawan tahun pelajaran 2017/2018".

Sudijono (2012, p.32) mengungkapkan hasil belajar merupakan sebuah tindakan evaluasi yang dapat mengungkap aspek proses berpikir (cognitive domain) juga dapat mengungkap aspek kejiwaan lainnya, yaitu aspek nilai atau sikap (affective domain) dan aspek keterampilan (psychomotor domain) yang melekat pada diri setiap individu peserta didik. Ini artinya melalui hasil belajar dapat terungkap secara holistik penggambaran pencapaian siswa setelah melalui pembelajaran (Tri ,2016).

\section{Metode}

Tempat penelitian ini adalah SD di Gugus I Kecamatan Sawan, Kabupaten Buleleng yang terdiri dari 5 sekolah Waktu penelitian ini dilaksanakan pada rentang waktu semester genap tahun pelajaran 2017/2018Penelitian ini dilaksanakan di gugus I kecamatan Sawan dengan menggunakan rancangan non equivalent post-test only control group design. Secara prosedural desain penelitian ini disajikan dalam Tabel 2.

Tabel 2. Desain Penelitian Non Equivalent Post-test Only Control Group Design

\begin{tabular}{ccc}
\hline Kelompok & Perlakuan & Post-Test \\
\hline Eksperimen & $\mathrm{X}_{1}$ & $\mathrm{O}_{1}$ \\
\hline Kontrol & - & $\mathrm{O}_{2}$ \\
\hline
\end{tabular}

(diadaptasi dari Sugiyono,2016)

Keterangan:

$\mathrm{X}_{1}$ : Perlakuan yaitu model pembelajaran Kooperatif Tipe Snowball Throwiing (Kelompok Eksperimen)

- $\quad$ : Perlakuan yaitu model pembelajaran konvensional (kelompok kontrol)

$\mathrm{O}_{1} \quad$ : Tes akhir (post-test) kelompok eksperimen

$\mathrm{O}_{2} \quad$ : Tes akhir (post-test) kelompok Kontrol

Desain penelitian eksperimen Non Equivalent Post-test Only Control Group Design dipilih karena eksperimen dilakukan di beberapa kelas tertentu dengan siswa yang telah ada atau sebagaimana adanya dan selama eksperimen tidak memungkinkan untuk mengubah kelas yang telah ada. 
Data yang dikumpulkan dalam penelitian ini adalah data tentang hasil belajar PKn siswa kelas IV di Gugus I Kecamatan Sawan. (Koyan 2012) menyatakan "Populasi adalah himpunan dari unsur-unsur yang sejenis. Unsur-unsur sejenis tersebut bisa berupa manusia, hewan, tumbuh-tumbuhan, benda-benda, zat cair, peristiwa, dan sejenisnya". Pada penelitian ini yang menjadi populasi adalah seluruh siswa kelas IV Gugus I kecamatan Sawan. Sampel penelitian adalah bagian dari jumlah dan karakteristik yang dimiliki oleh populasi tersebut (Sugiyono,2016). Pengambilan sampel secara dengan teknik random sampling bahwa kelas IV SDN 1 Sekumpul menjadi kelas eksperimen yang berjumlah 20 siswa dan Kelas IV SDN 2 Lemukih sebagai kelas kontrol yang berjumlah 18 siswa.

Data yang dikumpulkan dalam penelitian ini adalah tentang hasil belajar PKn. Arikunto (2011) alat adalah sesuatu yang dapat digunakan untuk mempermudah seseorang untuk melaksanakan tugas atau mencapai tujuan secara lebih efektif dan efisien Dalam penelitian ini, metode yang digunakan untuk mengumpulkan data adalah metode tes, dengan menggunakan tes objektif. Tes objektif digunakan diakhir pembelajaran. Suatu instrumen dikatakan baik jika instrumen tersebut memenuhi syarat validitas dan reliabilitas. Untuk mengetahui hal tersebut, maka instrumen harus diuji. Data yang diperoleh dari uji coba instrumen dianalisis dengan menggunakan uji validitas tes, reliabilitas tes, daya beda tes dan tingkat kesukaran tes. Data yang terkumpul, kemudian dianalisis dengan menggunakan teknik analisis deskriptif dan teknik analisi inferensial. Dan uji hipotesis menggunakan uji-t.

\section{Hasil dan Pembahasan}

Data yang di kumpulkan dalam penelitian ini yaitu data tentang hasil belajar PKn pada ranah kognitif yang diperoleh dari posttest setelah mengadakan 8 kali pertemuan pada masingmasing kelompok siswa yang dibelajarkan dengan menggunakan model pembelajaran kooperatif tipe Snowball Throwing Berbasis Penilaian Portofolio maupun siswa yang dibelajarkan dengan menggunakan model pembelajaran konvensional. Posttest dilakukan dengan memberikan soal pilihan ganda yang jumlahnya 30 soal yang telah di validasi. Banyakknya siswa yang dianalisis data belajar PKn pada kelompok kontrol eksperimen berjumlah 20 orang siswa dan pada kelompok kontrol berjumlah 18 orang siswa.

Distribusi frekuensi data hasil belajar PKn kelompok eksperimen yang dibelajarkan dengan menggunakan model pembelajaran kooperatif tipe Snowball Throwing berbasis penilaian portofolio, disajikan pada gambar 1 berikut.

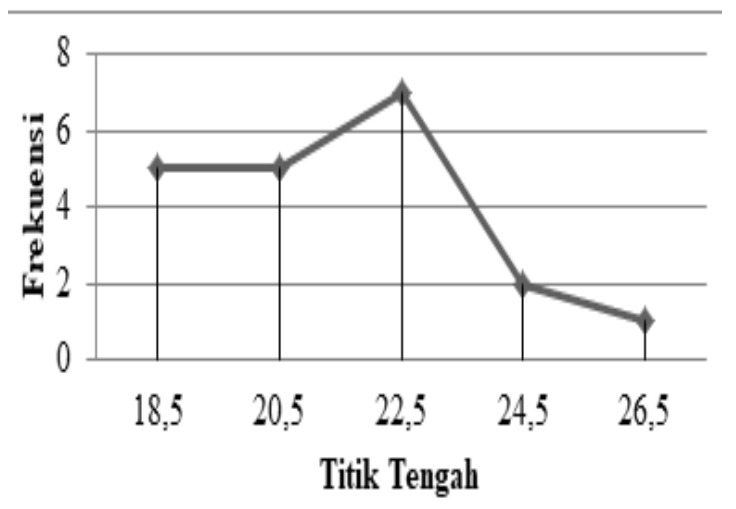

Gambar 1. Polygon kelompok Eksperimen

Berdasarkan Gambar 1 terlihat kelompok siswa yang dibelajarkan dengan menggunakan model pembelajaran kooperatif tipe Snowball Throwing berbasis penilaian portofolio menunjukkan kurva negatif $\mathrm{Mo}>\mathrm{Md}>\mathrm{M}(22>21,50>21,40)$. Hal ini menunjukkan skor cendrung tinggi. Distribusi frekuensi data hasil belajar PKn kelompok Kontrol yang dibelajarkan dengan menggunakan model pembelajaran konvensional, disajikan pada gambar 2 berikut. 


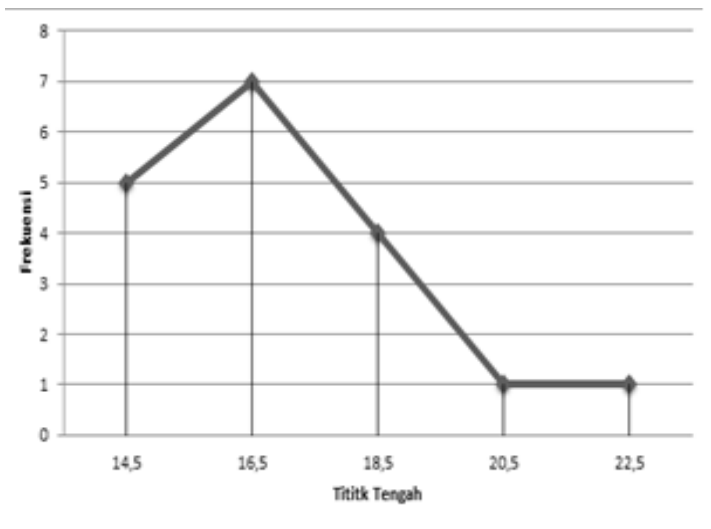

Gambar 2. Polygon kelompok control

Berdasarkan Gambar1 terlihat kelompok siswa yang dibelajarkan dengan menggunakan model pembelajaran konvensional menunjukkan kurva positif $\mathrm{Mo}<\mathrm{Md}<\mathrm{M}$ $(16,3<16,5<16,8)$. Hal ini menunjukkan skor cendrung sedang.

Berdasarkan nilai rata-rata hasil belajar PKn kelompok siswa yang dibelajarkan dengan model pembelajaran kooperatif tipe Snowball Throwing berbasis penilaian portofolio sebesar 21,40 dengan varians 9,30 dan standar deviasi 3,05. Sedangkan nilai rata-rata hasil belajar PKn kelompok siswa yang dibelajarkan dengan menggunakan model konvensional sebesar 16,80 dengan varians 5,29 dan standar deviasi 2,3. Ringkasan hasil pengujian normalitas sebaran data tersaji pada Tabel 3.

Tabel 3. Ringkasan Uji Normalitas sebaran Data.

\begin{tabular}{cccc}
\hline No & $\chi^{2}{ }_{\text {hit }}$ & $\chi^{2}$ & Keterangan \\
1 & 2,397 & 5,991 & Normal \\
\hline 2 & 2,306 & 5,991 & Normal \\
\hline
\end{tabular}

Keterangan:

1 : Kelompok Eksperimen

2 : Kelompok Kontrol

Berdasarkan perhitungan diatas hasil uji normalitas sebaran data hasil belajar PKn pada yang di uji dengan menggunakan analisis Chi-Kuadrat $\left(\chi^{2}\right)$ pada taraf signifikan $5 \%$ dan derajat kebebasan $\mathrm{db}=\mathrm{k}$-parameter $(\mathrm{db}=\mathrm{k}-2-1)$ diperoleh kelompok eksperimen $\chi^{2}{ }_{h i t}=2,397$ dengan $\mathrm{db}=2$ dan taraf signifikasi $5 \%$ sehingga di peroleh $\chi_{\text {tab }}^{2}=5,991 \mathrm{ini}$ berarti bahwa $\chi^{2}{ }_{h i t}<\chi_{\text {tab }}^{2}$, hal ini berarti data hasil belajar PKn siswa kelompok eksperimen berdistribusi normal. Sedangkan hasil belajar PKn siswa kelompok kontrol $\chi^{2}$ hit $=2,306$ dengan $\mathrm{db}=2$ dan taraf signifikasi $5 \%$ sehingga di peroleh $\chi_{\text {tab }}^{2}=5,991$ ini berarti bahwa $\chi^{2}{ }_{h i t}<\chi_{\text {tab }}^{2}$, hal ini berarti data hasil belajar PKn siswa kelompok kontrol berdistribusi normal. Ringkasan hasil uji Homogenitas varianas data hasil belajar PKn siswa di sajikan pada Tabel 4 berikut.

Tabel 4. Hasil Homogenitas Varians

\begin{tabular}{cccc}
\hline Sumber Data & $\mathbf{F}_{\text {hit }}$ & $\mathbf{F}_{\text {tabel }}$ & Status \\
\hline $\begin{array}{c}\text { Kelompok eksperimen dan } \\
\text { kontrol }\end{array}$ & 1,75 & 2,21 & Homogen \\
\hline
\end{tabular}


Data hasil perhitungan, diperoleh kelompok eksperimen dan kelompok kontrol yaitu $F_{\text {hitung }}=1,75$ dan $F_{\text {tabel }}=2,21$ dengan $d_{\text {pembilang }}=17, d_{\text {penyebut }}=19$, dan taraf signifikasi $5 \%$. Hal ini berarti $\mathrm{F}_{\text {hitung }}<\mathrm{F}_{\text {tabel }}$, sehingga varians data hasil belajar PKn dikategorikan homogen.

Berdasarkan uji prasyarat analisis data, diperoleh bahwa data hasil belajar PKn kelompok eksperimen dan kelompok kontrol berdistribusi normal dan memiliki varians yang homogen. Kriteria pengujian adalah $\mathrm{H}_{0}$ ditolak jika $t_{\text {hitung }} \geq t_{\text {tabel, }}$, sebaliknya jika $t_{\text {hitung }} \leq t_{\text {tabel }}$ maka $\mathrm{H}_{0}$ diterima dan $\mathrm{H}_{1}$ ditolak, Tabel 5 berikut.

Tabel 5. Ringkasan Hasil Uji Hipotesis Hasil Belajar PKn

\begin{tabular}{cccc}
\hline $\mathbf{D b}$ & $\mathbf{t}_{\text {hitung }}$ & $\mathbf{t}_{\text {tabel }}$ & Kesimpulan \\
\hline 36 & 5,679 & 2,028 & $\mathrm{t}_{\text {hitung }} \geq \mathrm{t}_{\text {tabel }} \mathrm{H}_{0}$ ditolak \\
\hline
\end{tabular}

Berdasarkan analisis data diperoleh $t_{\text {hitung }}$ sebesar 5,679 dibandingkan sengan $t_{\text {tabel }}$. Harga $t_{\text {tabel }}$ diperoleh darui tabel nilai-nilai distribusi $T$ dengan $\mathrm{dk}=20+18-2=36$ dan taraf signifikasi $5 \%$. Berdasarkan tabel nilai-nilai dalam distribusi $T$ diperoleh harga $t_{\text {tabel }}$ sebesar 2,028. Karena $t_{\text {hitung }} \geq t_{\text {tabel }}(6,216 \geq 2,028)$ maka $H_{0}$ ditolak dan $H_{1}$ diterima. Hal ini berarti terdapat pengaruh yang signifikan hasil belajar PKn kelompok siswa yang dibelajarkan dengan model pembelajaran kooperatif Tipe Snowball Throwing berbasis penilaian portofolio dan kelompok siswa yang dibelajarkan dengan model konvensional pada siswa kelas IV di Gugus I Kecamatan Sawan Tahun Pelajaran 2017/2018.

Hasil penelitian ini menunjukkan terdapat perbedaan hasil belajar PKn siswa yang dibelajarkan dengan model pembelajaran kooperatif tipe Snowball Throwing berbasis penilaian portofolio dengan siswa yang dibelajarkan dengan model pembelajaran konvensional. Hal ini dapat dilihat dari perbedaan nilai rata-rata hasil belajar PKn antara dua kelompok dan hasik ujit. Berdasarkan rata-rata skor hasil belajar PKn kelompok eksperimen lebih tinggi dari pada ratarata hasil belajar PKn siswa kelompok kontrol. Selain dilihat dari nilai rata-rata tersebut, perbedaan antara kelompok siswa yang dibelajarkan menggunakan model pembelajaran kooperatif tipe Snowball Throwing berbasis penilaian portofolio dan siswa yang dibelajarkan dengan menggunakan model pembelajaran konvensional juga dapat dilihat dari berdasarkan hasil analisis uji t pada taraf signifikansi $5 \%$. Berdasarkan hasil perhitungan tersebut diketahui

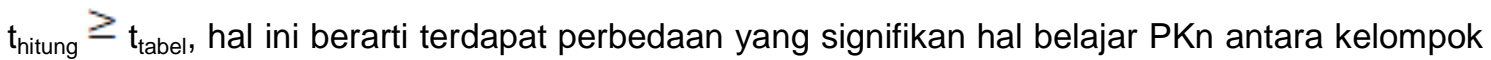
siswa yang dibelajarkan dengan menggunakan model pembelajaran kooperatif tipe Snowball Throwing berbasis penilaian portofolio dan siswa yang dibelajarkan dengan menggunakan model pembelajaran konvensional pada siswa kelas IV SD semester genap tahun pelajaran 2017/2018 di gugus I Kecamatan Sawan.

Pada penelitian ini ditemukan beberapa temuan, yaitu pertama sebelum diterapkan model pembelajaran kooperatif tipe Snowball Throwing berbasis penilaian portofolio nilai siswa belum mencapai KKM. Hal ini disebabkan karena guru masih menggunakan model pembelajaran konvensional sehingga siswa kurang aktif dalam proses pembelajaran. Dan tidak adanya dokumentasi nilai siswa juga merupakan salah satu faktor lemahnya semangat siswa dalam belajar, karena siswa tidak mengetahui tingkat pencapaiannya dalam proses pembelajaran yang telah dilaluinya. Kedua, setelah diterapkan model pembelajaran kooperatif tipe Snowball Throwing berbasis penilaian portofolio nilai rata-rata siswa berada dalam kategori tinggi, siswa menunjukan keaktifan dan semangat dalam mengikuti pembelajaran, dan adanya dokumentasi nilai siswa melalui penilaian portofolio. Pengaruh yang signifikan hasil belajar PKn antara kelompok siswa yang dibelajarkan dengan model pembelajaran kooperatif tipe Snowball Throwing berbasis penilaian portofolio dan kelompok siswa yang dibelajarkan dengan menggunakan model pembelajaran konvensional disebabkan karena beberapa faktor yaitu perlakuan perbedaan langkah-langkah dan proses pembelajaran.

Model pembelajaran kooperatif tipe Snowball Throwing berbasis penilaian portofolio pada kelompok eksperimen membuat siswa terlibat aktif dan menumbuhkan semangat siswa karena siswa akan di ajak bermain lempar bola pertanyaan sehingga tidak hanya menggunakan kemampuan berpikir tetapi juga akan menggunakan anggota tubuh. Hal ini sesuai dengan pendapat Huda (2013:226) bahwa Snowball Throwing merupakan pembelajaran yang diadopsi pertama kali dari game fisik dimana segumpalan salju yang dilempar dengan maksud memukul orang lain. 
Peranan model pembelajaran kooperatif tipe Snowball Throwing berbasis penilaian portofolio dalam proses pembelajaran yaitu membangkitkan semangat siswa dalam pembelajaran dan mengajak siswa belajar sambil bermain. Melalui beberapa langkah pada Langkah (1), guru menyampaikan seluruh tujuan dalam pembelajaran dan memotivasi siswa. Hal ini akan memberikan motivasi kepada siswa untuk mengikuti pembelajaran. Pada langkah (2) guru menyajikan informasi tentang materi pembelajaran siswa, pada langkah ini siswa akan diberikan informasi mengenai materi yang akan dipelajari. Hal ini akan menambah pengetahuan siswa. Langkah (3) Guru memberikan informasi kepada siswa tentang prosedur pelaksanaan pembelajaran Snowball Throwing dan Guru membagi siswa menjadi 2 kelompok besar, pada tahap ini siswa akan melakukan persiapan untuk melalukan permainan lempar bola pertanyaan. Hal ini akan memberikan sebuah gambaran mengenai permainan apa yang akan dilakukan oleh siswa. Langkah (4) Guru memanggil ketua kelompok dan menjelaskan materi serta pembagian tugas kelompok, Guru meminta ketua kelompok kembali kekelompoknya masingmasing, Guru meminta setiap kelompok untuk membuat pertanyaan dalam selembar kertas dan meremasnya dan berbentuk bola, Guru meminta siswa untuk saling melempar bola pertanyaan kekelompok lawan dan Guru meminta setiap kelompok menuliskan jawaban atas pertanyaan yang didapatkan dari kelompok lain pada kertas kerja tersebut. Pada langkah ini siswa sudah mulai lempar pertanyaan dan bermain Snowball Throwing sesuai dengan instruksi sebelumnya. Hal ini akan memberikan semangat belajar bagi siswa karena siswa diajak terlibat langsung dalam proses pembelajaran. Langkah (5) Guru meminta setiap kelompok untuk membacakan jawaban atas pertanyaan yang diterima darii kelompok lain. Pada langkah ini siswa yang membuat pertanyaan harus mampu menilai apakah jawab yang diberikan oleh temannya benar atau salah. Hal ini akan memberikan pengetahuan juga bagi pembuat pertanyaan dan yang menjawab pertanyaan. Dan langkah (6) Guru Memberikan penilaian terhadap hasil kerja kelompok, pada langkah ini guru memberikan penilaian atau memberikan konfirmasi mengenai pertanyaan dan jawaban yang telah di buat siswa.

Perbedaan cara pembelajaran antara kelompok siswa yang dibelajarkan dengan model pembelajaran kooperatif tipe Snowball Throwing berbasis penilaian portofolio dengan pembelajaran konvensional tentunya memberikan dampak yang berbeda pula terhadap hasil belajar siswa. Hasil penilaian ini juga diperkuat oleh penelitian yang dilakukan oleh Ni Putu Krisna Dewi (2017), bahwa perbedaan hasil belajar IPA menandakan model pembelajaran snowball throwing berpengaruh terhadap hasil belajar IPA siswa kelas V SD di Gugus IV Kecamatan Gerokgak, Kabupaten Buleleng tahun pelajaran 2016/2017.

Berdasarkan hasil penelitian diatas dapat disimpulkan bahwa terdapat pengaruh yang signifikan hasil belajar siswa yang dibelajarkan dengan model pembelajaran kooperatif tipe Snowball Throwing berbasis penilaian portofolio dengan siswa yang dibelajarkan dengan menggunakan model konvensional pada siswa kelas IV SD Gugus I Kecamatan Sawan Tahun Pelajaran 2017/2018.

\section{Simpulan dan Saran}

Model Pembelajaran Kooperatif tipe Snowball Throwing yaitu pembelajaran yang memberikan pemahaman kepada siswa melalui gumpalan bola pertanyaan dari kertas yang di gulung bulat berbentuk bola kemudian di lemparkan secara bergiliran di antara sesama anggota kelompok. Penilaian Portofolio merupakan kumpulan hasil belajar siswa yang dilakukan oleh guru dalam bentuk kertas yang menunjukkan prestasi dan kemajuan siswa dalam belajar. Dan model pembelajaran konvensional merupakan metode pembelajaran yang bersifat hapalan dengan penyajian pengalaman-pengalaman dan konsep yang akan dipelajari siswa selama proses pembelajaran.

Hasil belajar adalah kemampuan yang diperoleh siswa setelah melalui pengalaman belajarnya sebagai wujud pencapaian dalam proses belajar yang telah berlangsung. Pada kegiatan proses pembelajaran, terdapat mata pelajaran yang wajib ada di sekolah salah satunya PKn. Pendidikan Kewarganegaraan (PKn) adalah mata pelajaran yang dijadikan wahana dalam membentuk manusia yang memiliki rasa kebangsaan dan cinta tanah air sehingga mampu melestarikam nilai dan moral serta mampu hidup bersama-sama sebagai warga negara yang baik.

Jenis penelitian ini adalah penelitian eksperimen semu (quasi experiment). Adapun rancangan penelitian yang diguanakan adalag Non- Equivalent Posttest Only Control Group Design. Populasi dalam penelitian ini adalah seluruh kelas IV SD di gugus I kecamatan Sawan, 
berjumlah 118 siswa yang terbagi dari 5 SD yaitu: SDN 1 Lemukih, SDN 2 Lemukih, SDN3 Lemukih, SDN1 Galungan dan SDN 1 Sekumpul.

Sampel penelitian di tentukan dengan teknik random sampling bahwa kelas IV SDN 1 Sekumpul menjadi kelas eksperimen yang berjumlah 20 siswa dan Kelas IV SDN 2 Lemukih sebagai kelas kontrol yang berjumlah 18 siswa. Data yang dikumpulkan dalam penelitian ini menggunakan metode tes. Instrumen yang digunakan untuk pengumpulan data yaitu tes hasil belajar PKn dengan tes pilihan ganda atau tes objektif yang berjumlah 30 butir soal.

Pada kelompok siswa yang dibelajarkan dengan menggunakan model pembelajaran kooperatif tipe Snowball Throwing berbasis penilaian portofolio lebih besar dibandingkan dengan kelompok siswa yang dibelajarkan dengan menggunakan model pembelajaran konvensional $(21,40>16,80)$. Sebelum dilakukan uji hipotesis, terlebih dahulu dilakukan uji prasyarat yang meliputi uji normalitas dan uji homogenitas. Setelah diketahui sebaran data hasil belajar PKn kedua kelompok telah memenuhi uji prasyarat yaitu berdistribusi normal dan memiliki varians yang homogen, maka dilanjutkan dengan uji-t.

Berdasarkan hasil penelitian dan pembahasan di atas, maka dapat di simpulkan yaitu terdapat perbedaan yang signifikan hal belajar PKn antara kelompok siswa yang dibelajarkan dengan menggunakan model pembelajaran kooperatif tipe Snowball Throwing berbasis penilaian portofolio dan siswa yang dibelajarkan dengan menggunakan model pembelajaran konvensional. Hal ini dapat dilihat berdasarkan pengujian hipotesis dengan menggunakan uji t yang diketahui $t_{\text {hitung }}=5,679$ dan $t_{\text {tabel }} 2,028$ untuk db pada taraf signifikansi $5 \%$. Berdasarkan hasil perhitungan tersebut diketahui $\mathrm{t}_{\text {hitung }} \geq \mathrm{t}_{\text {tabel }}$ maka $\mathrm{H}_{0}$ ditolak dan $\mathrm{H}_{1}$ diterima. Selain itu juga dapat dilihat dari nilai rerata hitung, kelompok eksperimen memiliki rata-rata lebih tinggi dari pada kelompok kontrol $(21,40>16,80)$. Sehingga dapat disimpulkan bahwa model pembelajaran kooperatif tipe Snowball Throwing berbasis penilaian portofolio memiliki pengaruh signifikan terhadap hasil belajar PKn siswa kelas IV di Gugus I Kecamatan Sawan Tahun Pelajaran 2017/2018.

Adapun saran yang diajukan berdasarkan hasil penelitian dan pembahasan adalah sebagai berikut. Disarankan kepada siswa-siswa di SD agar lebih aktif dalam mengikuti pembelajaran dan mengembangkan pemahamannya melalui pengalaman belajarnya sehingga dapat meningkatkan hasil belajar, disarankan kepada guru-guru di SD agar dapat membangkitkan semnagat belajar siswa dengan melakukan inovasi model pembelajaran maupun strategi pembelajaran sehingga dapat meningkatkan hasil belajar siswa, disarankan kepada kepala sekolah agar selalu berusaha meningkatkan kualitas pembelajaran di sekolah, salah satunya melalui sossialisasi penerapan model pembelajaran yang inovatif sehingga dapat meningkatkan hasil belajar siswa.

Bagi peneliti selanjutnya diharapkan agar dapat memperhatikan kendala yang dialami dalam pelaksanaan model pembelajaran pembelajaran kooperatif tipe Snowball Throwing berbasis penilaian portofolio khususnya pada mata pelajaran PKn untuk penyempurnaan penelitian yang dilaksanakan.

\section{Daftar Pustaka}

Adnyana, I. G. O. (2017). Pengaruh Model Pembelajaran Snowball Throwing Berbasis Kearifan Lokal Terhadap Hasil Belajar Ips Siswa Kelas IV

Huda, M. (2013). Model-model Pengajaran dan Pembelajaran. Yogyakarta: Pustaka Pelajar.

Krisna Dewi, N. P. (2017). Pengaruh Model Pembelajaran Snowball Throwing Terhadap Hasil Belajar IPA Pada Siswa Kelas V SD.

Lestari, N. M. D. (2017). Pengaruh Model Pembelajaran Snowball Throwing Berbasis LaguLagu Anak Terhadap Kompetensi Pengetahuan PKn, 1, 163-168.

Murdiono, M. (2012). Strategi Pembelajaran Kewarganegaraan. Yogyakarta: Penerbit Ombak.

Nurkholis (2013). Pendidikan Dalam Upaya Memajukan Teknologi . Jurnal Kependidikan, Vol. 1 No. 1 Nopember 2013 
Monawati (2016). Upaya Meningkatkan Hasil Belajar Siswa Melalui Lesson Study Pada Penjumlahan Pecahan Di Kelas Iv Sdn Lamsayeun. JURNAL PESONA DASAR Universitas Syiah Kuala Vol. 3 No.4, Oktober 2016, hal 12-21 ISSN: 2337-9227

Ramlah (2017). Penerapan Metode Pembelajaran Kooperatif Tipe Snowball Throwing Untuk Meningkatkan Hasil Belajar Fisika Pada Siswa Kelas Xii Sman 9 Pekanbaru . Jurnal Pendidikan dan Pengajaran Program Studi Pendidikan Guru Sekolah Dasar FKIP Universitas Riau Volume 1 Nomor 1 Juli 2017

Rosidah ,Ani (2017) Penerapan Model Pembelajaran Kooperatif Snowball Throwing Untuk Meningkatkan Hasil Belajar Siswa Pada Pembelajaran Ips . Jurnal Cakrawala Pendas Vol. 3 No.2 Edisi Juli 2017

Sugianti, L. (2017). Pengaruh Model Pembelajaran Berbasis Masaah Berbantuan Assesment Portopolio Terhadap Hasil Belajar IPS Siswa Kelas IV. MIMBAR $P G S D, 5(2)$. Retrievedfromhttps://ejournal.undiksha.ac.id/index.php/JJPGSD /article/view/10925/7001

Susanto, A. (2013). Teori Belajar \& Pembelajaran di Sekolah Dasar. Jakarta: Kencana Prenada Media Grup.

Tri ,Budi (2016). Faktor-Faktor Yang Mempengaruhi Hasil Belajar Siswa Pada Pembelajaran Praktik Kelistrikan Otomotif Smk Di Kota Yogyakarta . Jurnal Pendidikan Vokasi Volume 6, No 1, Februari 2016

Wuryandani, W. \& F. (2012). Pembelajaran Pendidikan Kewarganegaraan di Sekolah Dasar. Yogyakarta: Penerbit Ombak.

UU No.20 Tahun 2003 tentang Sistem Pendidikan Nasional

Yuliati (2015). Efektifitas Penggunaan Model Kooperatif Tipe Snowball Throwing Untuk Meningkatkan Hasil Belajar Siswa Pada Materi Sistem Pertidaksamaan Linear Di Kelas Xi-Is-2 Sma Negeri 7 Banda Aceh . Jurnal Peluang, Volume 3, Nomor 2, April 2015, ISSN: 2302-5158 